\title{
THE ANALYSIS OF CONSTITUENT MATERIALS OF THE NAOS DOORS BELONGING TO THE WOODEN CHURCH FROM PETRINDU, SALAJ COUNTY
}

\author{
IOAN BRATU ${ }^{a}$ *, CONSTANTIN MARUTOIU ${ }^{\text {* }}$, DANA POSTOLACHE , \\ CLAUDIU TANASELIA ${ }^{\mathrm{d}}$, OLIVIA FLORENA NEMEŞ ${ }^{\mathrm{b}}$
}

\begin{abstract}
In order to preserve and restore the door that separate the Naos and Pronaos belonging to the wooden church of Petrindu, Salaj County, the scientific expertise (with FTIR, XRF spectroscopy and restoring) of the wooden stage and of the painting materials (ground, pigments) was performed. FTIR spectroscopy offers information about the wooden stage whereas XRF and FTIR spectroscopic methods were employed for structural painting materials characterization. These structural data can be correlated with the artistic, theological and historical analysis of this religious patrimony object. After obtaining information about wooden stage and the painting materials, the door was restored.
\end{abstract}

Keywods: wooden church, painting materials, XRF and FTIR spectroscopy

\section{INTRODUCTION}

The forested landscape of Salaj County contained various types of wood species. This made possible for the people to settle in those areas and to acquire the materials to build their homes and churches. The first

\footnotetext{
${ }^{a}$ National Institute for R\&D of Isotopic and Molecular Technologies, Cluj-Napoca, Romania

*Corresponding author ibratu@itim-cj.ro

${ }^{b}$ Babeş-Bolyai University, Faculty of Orthodox Theology, Cluj-Napoca, Romania

${ }^{c}$ University of Craiova, Faculty of Orthodox Theology, Romania

${ }^{d}$ INCDO-INOE 2000 Research Institute for Analytical Instrumentation, Cluj-Napoca, Romania
} 
documentary attestation of these localities dates from 1219 [1]. The Tartar and Ottoman invasions resulted in the disappearance of many wooden churches. More were destroyed by Christians like General Bucow (1760 1762 ) or by natural calamities. These adversities did not discourage the inhabitants who raised new churches replacing the destroyed ones. This is also the story of the Petrindu wooden church, Salaj County. The church was built in the Eighteen century, and in 1965 was moved to the "Romulus Vuia" National Ethnographic Park from Cluj-Napoca [2, 3].

The identification of pigments, binders, varnishes or other materials employed in manuscripts, ceramics and other artefacts were recognized for long time as important in understanding our cuttural heritage. The topic is an art-science border subject, being studied intensively by art historians, art curators and scientists involed in preservation and restoration belonging to those museums. Many techniques were employed for this purpose, among them several are specific for the chemical elemens present in pigments, for the molecular groups. One speeks on the electronic microscopy (SEM), X-ray fluorescence (XRF), gas and liquid chromatography coupled with massspectrometry, Raman and IR spectroscopy, etc. [4, 5]. Petrindu wooden church has a door separating the narthex and nave (Fig.1). This is a less common occurance in the wooden church architecture $[3,6]$.

Several Imperial Gates from various wooden churches and other religious objects were already investigated [7-10]. The aim of the paper is the scientific investigation of the painting materials and of the conservation state of the wooden backing (stand) of the gates that separate the Naos from Pronaos and belonging to the wooden church from Petrindu.
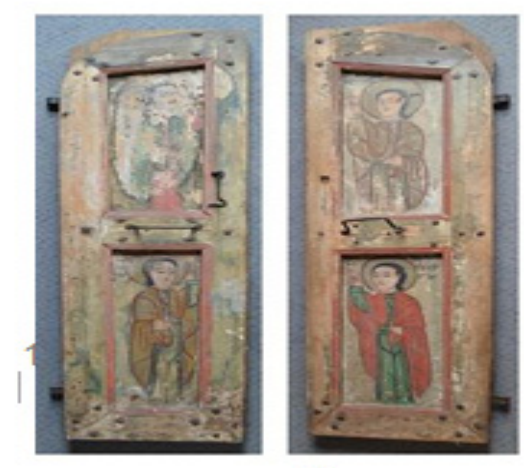

a

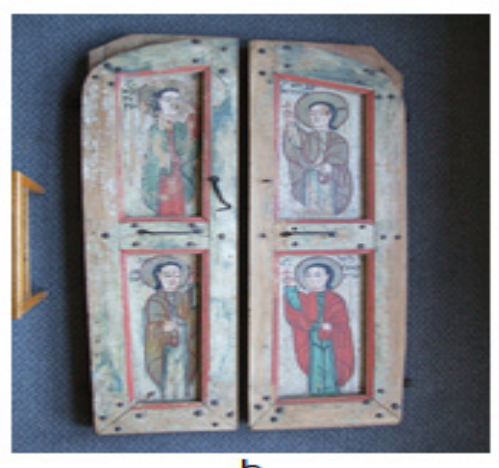

b

Figure 1. The door that separate the Naos and Pronaos belonging to the wooden church from Petrindu: a) before restoration $b$ ) after restoration 
THE ANALYSIS OF CONSTITUENT MATERIALS OF THE NAOS DOORS BELONGING ...

\section{RESULTS AND DISCUSSION}

XRF spectroscopic results

Based on the XRF data analysis presented in Table 1, one can propose the following composition of the painting materials employed: red door- $\mathrm{Pb}, \mathrm{Hg}$, As; yellow-As, $\mathrm{Cu}$; red cloths-Fe, As; black-Fe, As; red frame$\mathrm{Pb}=\mathrm{Hg}>\mathrm{As}$; green- $\mathrm{Cu}, \mathrm{As}$; aura-As; green Dimitrie clothes-As, Fe.

Table 1. XRF data for the investigated gates Set II (2 segment doors)

\begin{tabular}{|c|c|c|c|c|c|c|}
\hline Sample (door) & $\begin{array}{c}\mathrm{Fe} \\
\mathrm{mg} / \mathrm{kg}\end{array}$ & $\begin{array}{c}\mathrm{Cu} \\
\mathrm{mg} / \mathrm{kg}\end{array}$ & $\begin{array}{c}\mathrm{Zn} \\
\mathrm{mg} / \mathrm{kg}\end{array}$ & $\begin{array}{c}\text { As } \\
\mathrm{mg} / \mathrm{kg}\end{array}$ & $\begin{array}{c}\mathrm{Hg} \\
\mathrm{mg} / \mathrm{kg}\end{array}$ & $\begin{array}{c}\mathrm{Pb} \\
\mathrm{mg} / \mathrm{kg}\end{array}$ \\
\hline Red door Nave-Narthex (Left) & 357 & $<\underset{a}{L}$ & 68 & 4104 & 16871 & 16871 \\
\hline Green (Left) & 1324 & 19583 & 789 & 11865 & 227 & 227 \\
\hline Yellow clothing (Left) & 1226 & $\underset{a}{<L D}$ & 63 & 11041 & $<\underset{a}{<O O D}$ & $\underset{a}{<L_{a}}$ \\
\hline White face (Left) & 253 & $\underset{a}{<\mathrm{LOD}}$ & 84 & 112 & 170 & 170 \\
\hline Red clothing (Left) & 5852 & 76 & 97 & 9273 & 192 & 192 \\
\hline Black (Left) & 1165 & $\underset{a}{<L O D}$ & 289 & 4689 & 76 & 76 \\
\hline Red casing (Left) & 1420 & $<\underset{a}{<O D}$ & 1394 & 13603 & 73689 & 73689 \\
\hline Green (Right) & 1571 & 21379 & $\underset{\mathrm{a}}{<\mathrm{LOD}}$ & 13709 & 201 & 201 \\
\hline Red (Right) & 739 & $\underset{a}{<O D}$ & 85 & 6963 & 31255 & 31255 \\
\hline White (Right) & 504 & $\underset{a}{<\mathrm{LOD}}$ & $<\underset{a}{<L O D}$ & 137 & 302 & 302 \\
\hline Black (Right) & 1389 & 32 & $\underset{a}{<L O D}$ & 232 & 343 & 343 \\
\hline Aura (Right) & 976 & $\underset{\mathrm{a}}{<\mathrm{LOD}}$ & $\underset{a}{<L O D}$ & 5099 & 25 & 25 \\
\hline Red Saint George (Right) & 1215 & $<_{a}^{L O D}$ & 72 & 4560 & 21668 & 21668 \\
\hline Green clothing Dimitrie (Right) & 1813 & $<_{a} \operatorname{LOD}^{\prime}$ & $<\underset{a}{<L O D}$ & 9417 & 23 & 23 \\
\hline Red casing (Right) & 1023 & $\underset{a}{<\mathrm{LOD}}$ & 75 & 5033 & 22678 & 22678 \\
\hline
\end{tabular}




\section{FTIR spectroscopy results}

FTIR data obtained for the painting and of the wooden materials are presented in the Figures 2-3.

The significance of the painting materials is given in Table 1.

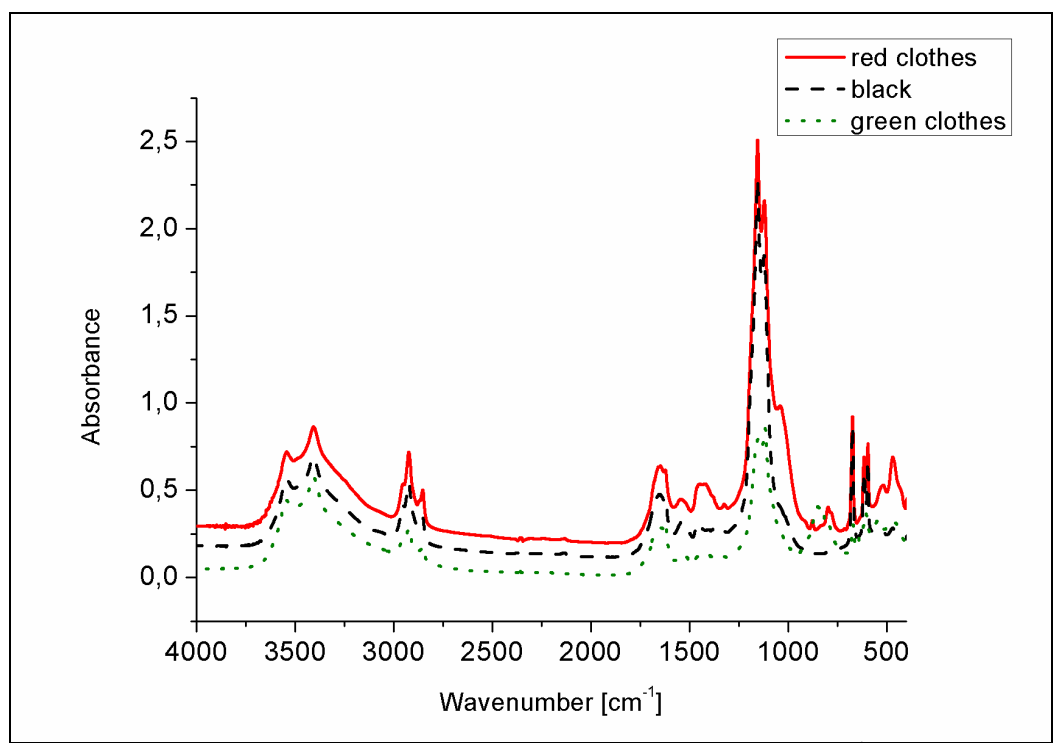

Figure 2. FTIR spectra of the painting materials, $4000-400 \mathrm{~cm}^{-1}$ spectral domain

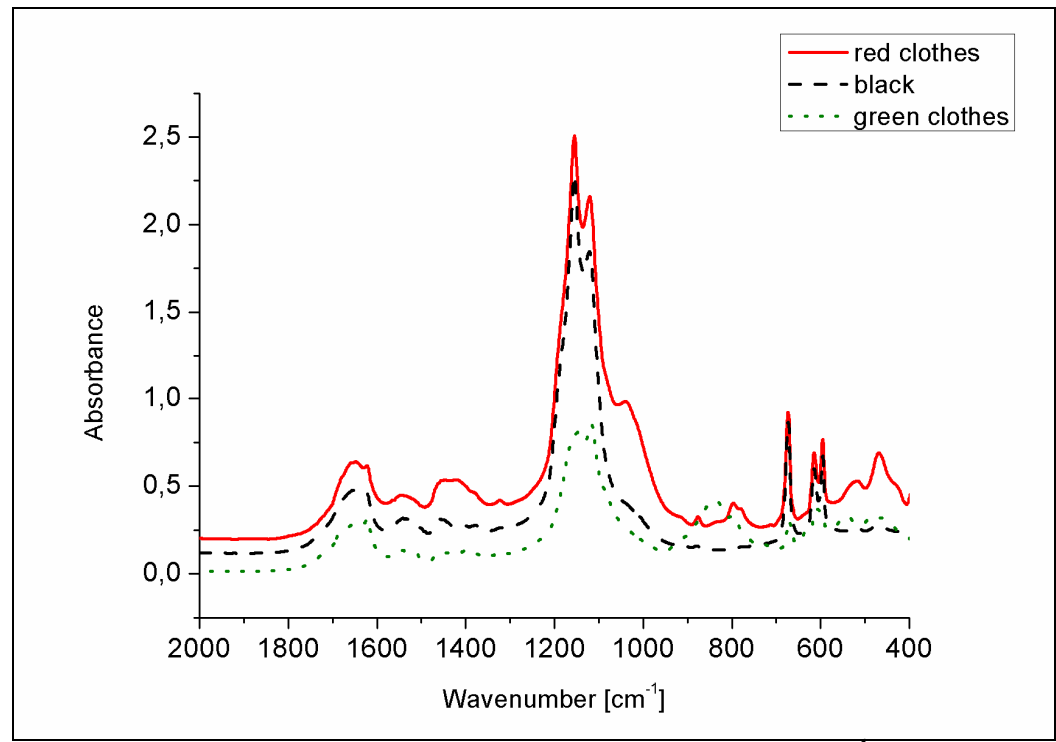

Figure 3. FTIR spectra of the painting materials, $2000-400 \mathrm{~cm}^{-1}$ spectral domain 
Composition, deduced from FTIR spectra analysis: red lead (470 and $\left.517 \mathrm{~cm}^{-1}\right)$, gypsum $(3543,3406,1623,1422,1155,1120,644$ and $\left.595 \mathrm{~cm}^{-1}\right)$, traces of carbonate $\left(\sim 1422\right.$ and $\left.877 \mathrm{~cm}^{-1}\right)$, aliphatics $(2953$ $\mathrm{cm}^{-1}$-methyl, 2924 and $2854 \mathrm{~cm}^{-1}$ - methylene), proteins (1648, 1541, $1323 \mathrm{~cm}^{-1}$ ), carbon black. Fig. 4 presents FTIR spectra of different wooden stages.

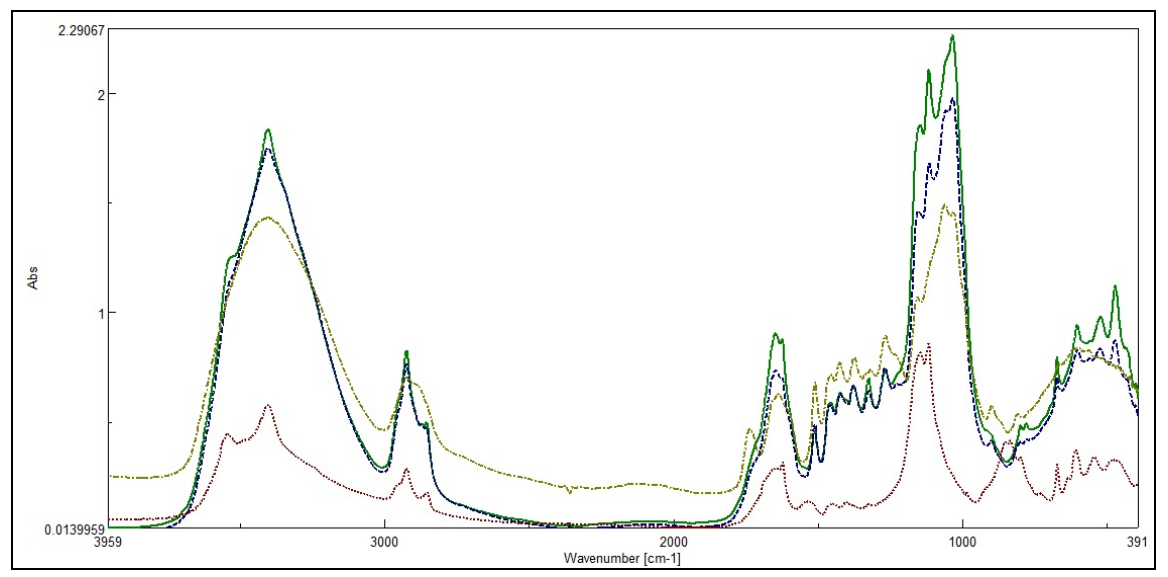

Figure 4. FTIR spectra of door's wood (continuous line), of back wood (dash line), of green St George cloth (dot line) and of fir wood (dash-dot line)

One can conclude that fir wood was employed for these doors. A report of the wood conservation state is presented in Table 2.

Table 2. Wood conservation state

\begin{tabular}{|c|c|c|c|c|}
\hline Sample & I $_{\mathrm{cr}}$ & $\mathrm{TCl}$ & $(\mathrm{L} / \mathrm{C})_{1}$ & $(\mathrm{~L} / \mathrm{C})_{3}$ \\
\hline Nave / narthex wood & 0.83 & 0.81 & 1.53 & 1.11 \\
\hline Back side wood & 0.99 & 0.87 & 1.80 & 1.19 \\
\hline Modern fir wood & 1.03 & 1.32 & 1.47 & 1.19 \\
\hline
\end{tabular}

The crystallinity decreases for historical wood as compared to modern one (see for example the $\mathrm{I}^{1} \mathrm{cr}$ and $\mathrm{TCl}$ factors in Table 2). The 
cellulose content decreased in time as compared to lignin one if we compare the $(\mathrm{L} / \mathrm{C})_{1}$ si $(\mathrm{L} / \mathrm{C})_{3}$ ratios. If we see the background wood, its crystallinity decreased more rapidly in time (see the $\mathrm{I}^{1} \mathrm{cr}$ and $\mathrm{TCl}$ ratios), whereas the $(\mathrm{L} / \mathrm{C})_{1}$ increased in time due to a more rapid cellulose consumption than the lignin one.

The wooden assembly after restoration

The wooden assembly after restoration is presented in Figure $\mathbf{1 b}$. The methodological approach was established and implemented in conformity with the scientific conservation-restoration principles, original technique, and state of conservation and the results of preliminary research, which was constituted by a set of interventions: gap filling of the support, consolidation of the paintings' layers, removal of dirt deposits, chromatic integration and final coating.

\section{CONCLUSIONS}

N-P doors are made from fir wood and the following painting materials were employed: red-red lead, Cinnabar, iron red and red arsenic; yellow-orpiment; black-iron arsenic; green-copper, calcium carbonate, gypsum, proteins.

The conservation-restoration methodology rendered the aesthetic unity of the painted wooden doors; the interventions were based on the minimum intervention principle as well as the interventions on the interior mural paintings (distemper paint) of the wooden church. By consolidation interventions, the cohesion of the painting layers with all its qualities were recovered, respectively the elasticity and flatness parameters. The original aesthetic imagery was recovered by the interventions of dirt deposits removal and the image disruptions caused by the extended lacunae and erosions were altered by means of chromatic retouching of the erosions.

\section{EXPERIMENTAL SECTION}

The door that separated the two chambers is made from two wooden pieces anchored by the wall using hinges (Fig. 2). The doors are painted by Dimitri Ispas from Gilau and each door is divided in two scenes, each portraying a saint. The door to the right measures 146 by $41.5 \mathrm{~cm}$ and portrays Saint George and Saint Dimitrie. The door to the left measures 146 by $40 \mathrm{~cm}$ and portrays Saint Martyr Nestor and Saint Martyr Lup. The painting was executed in Tempera on wood. 
$X$-ray fluorescence measurements were performed in situ using an INNOV-X Alpha- 6500 portable instrument ( $35 \mathrm{kV}$ voltage, $15 \mu \mathrm{A}$ intensity, 3 $\mathrm{mm}$ filter, Be window, 2 square $\mathrm{mm}$ spot size and PIN Si detector). Integration time was set to 60 seconds, in two consecutive runs of 30 seconds each. FTIR measurements were done with a JASCO 6100 spectrometer in the 4000 to $400 \mathrm{~cm}^{-1}$ spectral range with a resolution of 4 $\mathrm{cm}^{-1}$ employing the $\mathrm{KBr}$ pellet technique-

\section{Wood preservation status}

In order to determine the preservation status of the Imperial Gates' wood, several indexes are defined [11]: $I_{c r}{ }^{1}=A_{1377} / A_{669}$, or as $T C l=A_{1378} / A_{2925}$ (Total Crystallinity Index) and LOI= $\mathrm{A}_{1426} / \mathrm{A}_{895}$ ) (Lateral Order Index), A being the absorbance at maximum for each absorption band. The lignin/cellulose ratios, defined as [12] $(\mathrm{L} / \mathrm{C})_{1}=\mathrm{A}_{1506} / \mathrm{A}_{1738}$ and $(\mathrm{L} / \mathrm{C})_{3}=\mathrm{A}_{1506} / \mathrm{A}_{895}$ were calculated for wooden samples in agreement to these definitions. They can be used only as a measure of their evolution in time.

For an optimal methodological approach of the restoration of the wooden painted doors, consolidation and cleaning preliminary tests were done. Consequently, the consolidation of the painted layer was done using the aqueous solution of fish glue, in a very poor concentration, which rendered best the cohesion of the painting layers. The removal of dirt deposits was done by the use of tested solvent mixtures and mechanically with a surgical scalpel, both on the verso and recto of the doors. Chromatic attenuation of the erosions and lacunae was done using rittocco and velatura techniques with water-based colours. In the end, the whole painted surface was coated by a protective thin layer, which also has an important aesthetic role in controlling the glossiness of the painting.

\section{DISCLOSURE}

I. Bratu and C. Marutoiu are co-first authors

\section{ACKNOWLEDGMENTS}

Thanks are due to UEFISCDI for financial supporting on PN II-PTPCCA-2013-4-1882 project 


\section{REFERENCES}

1. Nicolae lorga, Istoria bisericii românești și a vieții religioase a românilor, vol. I, cap. III, „Cele d'intaiu biserici romanesti”, Tipografia „Neamul Românesc”, Vălenii-de-Munte, 1908.

2. Ioana Cristache-Panait,, Bisericile de lemn din Sălaj”. Buletinul Monumentelor Istorice 1971, 1, 31.

3. Leontin Ghergariu, Meșterii construcțiilor monumentale de lemn din Sălaj”. Anuarul Muzeului Etnografic al Transilvaniei, editia 1971-1973: 255-273, Cluj.

4. L. Burgio, R.J.H. Clark,, L. Sheldon, G.D. Smith, Analytical Chemistry 2005, 77, 1261.

5. Andreotti, L. Bonaduce, M.P. Colombini, G. Gautier,. F Modugno,. E Ribechini, Analytical Chemistry, 2006, 78, 4490.

6. Ioan Godea, Ioana Cristache-Panait, Monumente istorice bisericesti din Eparhia Oradei, judetele Bihor,Salaj si Satu-Mare. Bisericile de lemn, Ed. Episcopiei Ortodoxe Romane a Oradei, Oradea, 1978

7. Măruţoiu, I. Bratu, L.Troşan, C. Neamtu, V.C. Măruţoiu, D. Pop, C.Tănăselia, S. Garabagiu, Spectrochim Acta A, Molecular and Biomolecular Spectroscopy, 2016, 152, 311.

8. Măruțoiu, I. Bratu, A.M. Budu, Gh. Şanta, O. F. Măruțoiu, C. Neamțu, C. Tănăselia, I. Kacso, I. C. A. Sandu, Revista de Chimie, 2015, 66 (7) 992.

9. Măruţoiu, L. Troşan, V-D. Toader, Z. Moldovan, Al. I. Turza, C. Tãnãselia and I. Bratu, Studia UBB Chemia., 2013, 58 (4), 161.

10. Hernanz, I. Bratu, O.F. Măruţoiu, C. Măruţoiu, J. M. Gavira-Vallejo, H.C.M. Edwards, Analytical and Bioanalytical Chemistry, 2008, 392, 1-2. 263.

11. M. Popescu, Y. Sakara, M. C. Popescu, A. Osaka and C. Vasile, e-Preservation Science, 2005, 2, 19.

12. C.M., Popescu, M.C Popescu, C Vasile, International Journal of Biological Macromolecules, 2011, 48(4), p.667. 